УДК 378.147+37.032 \title{
Української інженерно-педагогічної академії \\ РОЗВИТОК МІЖКУЛЬТУРНОЇ КОМПЕТЕНТНОСТІ ПІД ЧАС НАВЧАЛЬНИХ ПРАКТИК СТУДЕНТІВ СПЕЦІАЛЬНОСТІ ДИЗАЙН МОДИ
}

Катерина Рябчикова, аспірант кафедри педагогіки, методики та менеджменту освіти (м. Харків)

У статті розглядаються проблеми організаиії закордонних навчальних практик, як основна умова формування практичної складової міжкультурноӥ компетентності майбутнього фахівия в галузі дизайну одягу. Обтрунтовані рівні і етапи практичної підготовки фахівиів галузі дизайн одягу при формуванні міжкультурної компетентності. Види $i$ призначення практик описані в алгоритмі проблеми - иілі - мотивації матеріалізація - рефлексія. Етапи та рівні практик зіставлені з основним дескрипторами формування міжкультурної компетентності.

Ключові слова: міжкультурна компетентність, дизайн одягу, навчальна практика, дескриптори.

The article deals with the problems of organizing of foreign educational practices, as the main condition for the formation of a practical component of intercultural competence of a future specialist in the field of clothing design. Levels and stages of practical training of specialists in the field of design of clothing in the formation of intercultural competence are grounded. Types and purposes of practice are described in the algorithm of the problem - goals motivation - materialization - reflection. It is proved that similar levels of distribution of educational practices aimed at the formation of intercultural competence logically correspond to the Dubin descriptors of competence formation. The proposed structure of practices forms the basic descriptors in the form of knowledge - skills - communication - autonomy and responsibility. The proposed structure is logically linked to the recommendations of the euro commission, practically tested and can be recommended for widespread adoption.

Key words: intercultural competency, design of clothes, educational practice, descriptors. 
Спеціальності, пов'язані з дизайном одягу динамічно розвиваються в вищий освіті України. Особливості сучасного періоду розвитку вищої освіти визначаються зростаючим впливом глобальних процесів, розширенням студентської і академічної мобільності. Напрямок дизайну одягу у цьому сенсі має особливий загальноєвропейський i загальносвітовий вплив. Пов'язано це 3 тим, що світові тренди моди знаходяться поки що в розвинутих європейських країнах, між тим, як виробництво предметів одягу розташовується, в основному в східних країнах., які, в свою чергу, створюють тиск на моду заходу.

Україна, певною мірою знаходиться на межі цих двох напрямів, що визначає, певною мірою, необхідність для нашої освіти знаходити точки дотику з багатьма країнами та культурами світу.

Базовим напрямом сучасної освіти вважається компетентнісний підхід до формування іï змісту. Перелік фахових компетентностей, необхідних для формування спеціалісту певного профілю визначається змістом освітньо-професійних програм. В іноземній літературі в останній час широко розповсюджуються дослідження в напрямку формування міжкультурної компетентності, що визначає здатність особи працювати за обраною спеціальності в умовах інших країн або культур [1-2].

Загальне розуміння компетентності, як комплексу знань, умінь, комунікацій, автономності і відповідальності згідно Дублінських дескрипторів [3] визначає необхідність комплексного підходу до навчання. Якщо компонент одержання знань припустимий для формування в навчальній аудиторії, інші складові компетентностей найбільш ефективно формувати під час практичної підготовки у вигляді навчальних практик, стажувань тощо.

В науково-педагогічній літературі чимало місця приділено ролі практики в формуванні умінь і інших практичних навичок [4]. Значення практики для спеціальностей швейного профілю і напряму «Дизайн одягу» описано в [5-6], хоча значення інтеркультурної практики для цих спеціальностей не відображено. В роботах [7-8] викладений досвід закордонної практики студентів українських університетів, хоча в основному така практика трактується, як мовно-лінгвістична.

В роботі [9] запропонований підхід у вигляді творчих практик, що плануються, як інтегративні форми навчання для розширення міжкультурної компетентності. При цьому практики інтегруються 3 спеціальними міжкультурними завданнями і стандартними підходами, що забезпечує формування інтегральної компетентності.

В роботі [10] визначені основні реакції етнокультурних груп з точки зору таких культурних аспектів, як раса, стать, національність. Інструктор практичного навчання повинен відповідати п'яти принципам 1) володіння інструктора теорією пізнання, 2) визнання різних систем знань, 
3) навчання на основі запиту, 4) включення вибору учня, 5) розширене використання нормативного зворотнього зв'язку.

В роботі [11] відзначається важливість попередньої теоретичної підготовки в галузі дослідження культури перед проходженням практики. Аналіз роботи викладачів в іншому культурному середовищі показав, що вони повинні були в ході практики розуміти нове організаційне і культурне оточення. В роботі обговорюється можливість нормалізувати перехідний етап при проходженні практики в умовах іншої культури.

Важливість міжнародного освітнього досвіду для студентів підкреслюється в [12]. Відзначаються соціальні, перехідні міжкультурні проблеми, які супроводжують початок таких практик i пов'язані 3 міжособистісними відношеннями. Такі практики забезпечують більш глибоке розуміння ролі міжнародних партнерств в сприянні академічному зростанню і підвищенню міжкультурної компетентності.

$\mathrm{y}$ роботі [13] розглянуті питання розробки програми короткострокового навчання за кордоном і зроблені висновки про вплав таких практик не тільки на формування міжкультурної компетентності, але й на професійні уміння і переконання.

Робота [14] доводить, що переваги міжкультурного і особистісного розвитку, одержані в ході проходження практики або навчання за кордоном, надають значний опосередкований вплив на студентську підприємливість. Таки закордонні практики значно полегшують занурення в життя і культуру іншої країни. Розглянуті питання міжкультурного ефекту при проведенні навчальних практик в країнах 3 малою і великою культурними дистанціями.

У [15] відзначено, що проходження міжнародних стажувань підвищує міжкультурну чутливість, професійний рівень, підвищення відомостей про вплив культури на професійну діяльність. Однак для досягнення цих бажаних результатів необхідна цілеспрямована підготовка. Авторами даної роботи рекомендований додатковий навчальний курс для студентів, що готуються до міжнародних стажувань. Навчальна програма цієї дисципліни направлена на те, щоб допомогти студентам підвищити самосвідомість і критичне відношення до своєї культури, розвити сприйняття культурних цінностей і особливостям організації професійної діяльності в країні призначення і вивчити практичні аспекти міжнародних поїздок і проживання за кордоном.

Мета статті - скорегувати систему практичної підготовки студентів дизайнерів з точки зору формування міжкультурної компетентності на основі етапів і рівнів проходження навчальної практики.

Розглядаючи будь-яку практику, як елемент навчального процесу, слід визначити певні риси і етапи цього процесу. Формування певної складової компетентності, що забезпечується етапом навчального процесу 
будемо проектувати у вигляді поетапного процесу у вигляді.

Етап проблематизації. В процесі підготовки до навчальної практики необхідно усвідомити проблему, що буде розв'язуватись під час іiі проходження. Треба усвідомлювати, що дійсне формування компетентностей повинно формуватися в процесі практичної діяльності. Студент повинен проходити через передолання утруднень, що виникають в реальному житті, тому, можливо, в процесі проектування завдання на практику педагог повинен передбачати певні штучні проблемні ситуації.

Етап концептуалізації передбачає формування здібностей, що визначають єдність розуміння основних понять і визначень, що повинні використовуватись під час практики.

Етап формування цілей включає практичне осмислення студентом бажаного результату практики. Формування цілей повинно відповідати рівню підготовки практиканта і можливостям рівня практичної підготовки.

Етап мотивації формує інтерес студента до результатів проходження практики. Такий інтерес може виступати у вигляді ситуативного інтересу, коли студент мотивується на продовження навчання i наступне формування міжкультурної компетентності, стійкого інтересу, коли студент усвідомлює важливість практичного навчання для набуття професійних міжкультурних компетентностей, інтересу - ставлення, при якому виявляється важливість набутих компетентностей в напрямку визначення сенсу життя.

Матеріальний етап проведення практики передбачає виконання основних дій щодо виконання поставленої цілі.

Етап рефлексії визначає самооцінку спів падання одержаних результатів поставленим цілям.

3 метою формування практичних навичок при формуванні міжкультурної компетентності майбутніх дизайнерів одягу в Українській інженерно-педагогічній академії передбачено проведення різнорівневих навчальних практик на протязі навчання (рис. 1).

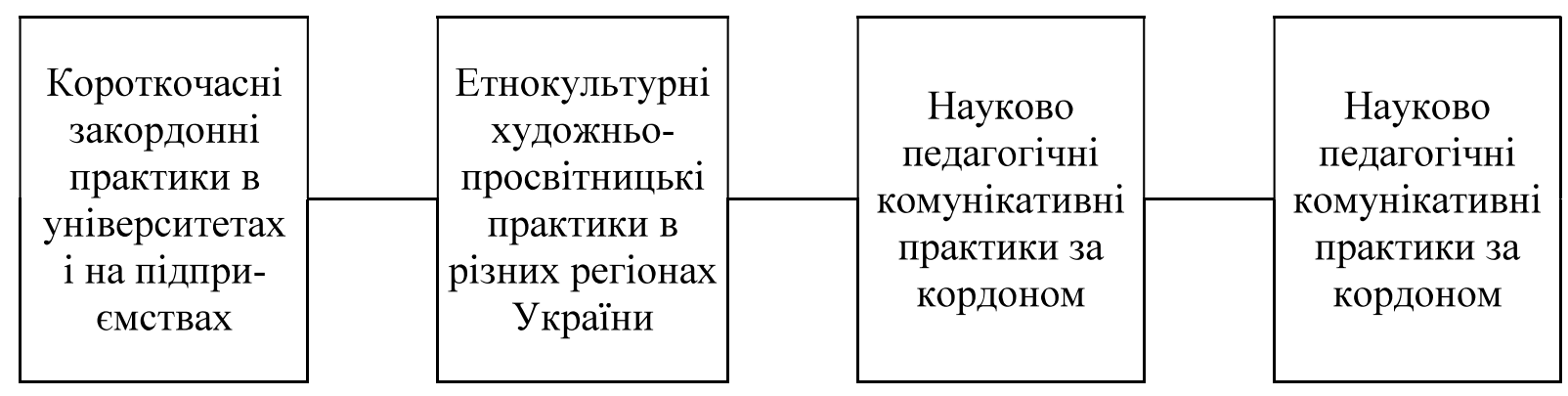

Рис. 1. Система навчальних практик для формування міжкультурної компетентності

Основні педагогічні задачі і умови таких практик наведені в таблиці. 


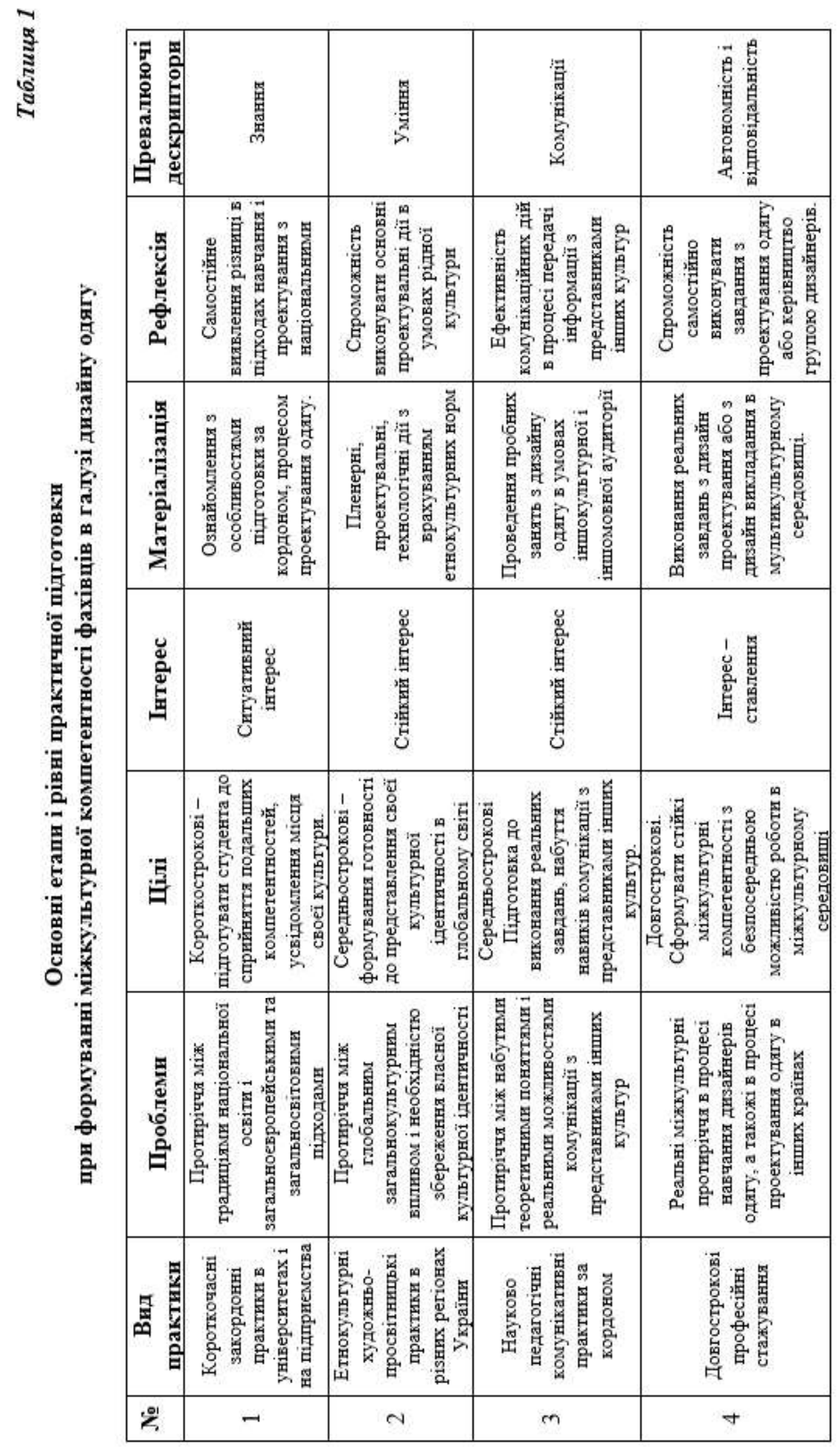


Короткочасні закордонні практики в університетах i на підприємствах передбачають розв'язання протиріччя між традиціями національної освіти i загальноєвропейськими та загальносвітовими підходами. Прикладом такої практики може відвідування групами студентів дружнього Ліберецького технічного університету (Чеська республіка), Міланської академії NABA (Італійська республіка).

Наступним етапом формування міжкультурної компетентності можуть виступати етнокультурні художньо-просвітницькі практики в різних регіонах України, що передбачають пленерні, проектувальні, технологічні дії 3 врахуванням етнокультурних норм, формують повагу до своєї культури в загальносвітовій системі культурних цінностей, визначають спроможність виконувати основні проектувальні дії в умовах рідної культури.

Наступним рівнем практичної підготовки виступають науково педагогічні комунікативні практики за кордоном, які, проводились, наприклад на основі договорів з Спеціальною школою економіки і бізнесу м. Прешов (Словацька республіка). В процесі проведення занять з дизайну одягу для учнів закордонних навчальних закладів формуються комунікаційні умови, уміння спілкуватися в іншомовній аудиторії на англійській мові (враховуючи, що англійська мова не є рідною також і для навчальної аудиторії), поважне ставлення до культурних особливостей інших країн, уміння використовувати ці особливості в роботі.

Вищою формою практичної підготовки фахівців дизайну одягу можуть бути довгострокові професійні стажування. Такі стажування, зокрема можуть проводитися на основі світової молодіжної організації AIESEC. Прикладами таких стажувань можуть бути піврічне стажування на посадах викладачів дизайну одягу в академії дизайну Arch Academy (м. Джайпур, Індія) в 2015-2016 роках, або участь у міжнародному дизайн проекті університету м. Коломбо (Шрі-Ланка) в 2017 році. Подібні практики формують спроможність до виконання реальних завдань 3 дизайн проектування або з дизайн викладання в мультикультурному середовищі.

Обгрунтовані рівні і етапи практичної підготовки фахівців галузі дизайн одягу при формуванні міжкультурної компетентності. Види i призначення практик описані в алгоритмі проблеми - цілі - мотивації матеріалізація - рефлексія.

Подібні рівні розподілення навчальних практик, направлених на формування міжкультурної компетентності логічно відповідають Дубінським дескрипторам формування компетентностей [3]. При цьому на різних етапах практичної підготовки у якості превалюючого поряд 3 іншими виступає окремий дескриптор. Так, в процесі проходження короткочасних закордонних практик в університетах і на підприємствах 
основним результатом формування міжкультурної компетентності виступає дескриптор «знання», під час проведення етнокультурних художньопросвітницьких практик в основному формується дескриптор «уміння», науково педагогічні комунікативні практики за кордоном, як основний, визначають дескриптор «комунікації», довгострокові професійні стажування - дескриптор «автономність і відповідальність». Таким чином, запропонована структура логічно пов'язана з рекомендаціями євро комісії, практично апробована i може бути рекомендована для широкого впровадження.

\section{СПИСОК ВИКОРИСТАНИХ ДЖЕРЕЛ}

1. Onorati M. G. Cultural displacement as a lever to global-ready student profiles: results from a longitudinal study on International Lifelong Learning Programs (LLP) / Onorati M. G., d'Ovidio F. D., Antonucci L. // Quality and Quantity. - 2017. -51(2). - Pp. 545-563.

2. Waldron R. Positionality and reflexive interaction: a critical internationalist cultural studies approach to intercultural collaboration / Waldron R. // Innovations in Education and Teaching International. - 2017. - 54(1). Pp. 12-19.

3. ECTS Users' Guide, European Union, 2015, 109 p. http://ec.europa.eu/ education/ects/users-guide/docs/ects-users-guide_en.pdf

4. Бутиліна О.В. Навчальна практика як чинник професіоналізації студентів / Бутиліна О. В., Кудринська А. І. // Вісник Харківського національного університету внутрішніх справ. - 2015. - № 1. C. $182-190$.

5. Попова Т. I. Розвиток професійно-творчих умінь у майбутніх дизайнерів одягу / Т. І. Попова // Проблеми інженерно-педагогічної освіти. - 2013. - № 38-39. - С. 326-332.

6. Попова Т. І. Організація різнорівневого виробничого навчання для спеціальностей швейного профілю на основі диференційованого підходу / Т. І. Попова // Молодь і ринок. - 2014. - № 1. - С. 56-62.

7. Бутиліна О. В. Навчально-методична практика студентів Львівського університету за кордоном / О.В.Бутиліна // Теорія і практика викладання української мови як іноземної. - 2012. - Вип. 7. - С. 266-267.

8. Процик I. Docendo discimus або навчальна практика студентівукраїністів Франкового університету у Вроцлавському університеті / I. Процик // Теорія і практика викладання української мови як іноземної. - 2013. - Вип. 8. - С. 379-381.

9. Andryukhina L. M. Creative practices in developing intercultural communicative competence / Andryukhina L. M., Fadeyeva N. Yu. // Integration of Education 20(3), pp. 320-330 2016 
10. Turning good intentions into good teaching: Five common principles for culturally responsive pedagogy (Book Chapter) / Hailu M., Mackey J., Pan J., Arend B. // Promoting Intercultural Communication Competencies in Higher Education. - 2016. - Pp. 20-53.

11. Buchanan J. Understanding the other through international professional teaching experiences / J. Buchanan // International Education Journal. 2017. - 16(4). - C. 3-28.

12. Lang $\mathrm{C}$. The global education practicum: perspectives from accompanying academics Asia-Pacific / Lang C., Cacciattolo M., Kidman G. // Journal of Teacher Education. - 2017. - 45(2). - Pp. 145-161.

13. He Y. Impact of short-term study abroad program: Inservice teachers' development of intercultural competence and pedagogical beliefs / He Y., Lundgren K., Pynes P. // Teaching and Teacher Education. - 2017. - 66. Pp. 147-157.

14. Mody M. Study abroad and the development of college students' travel venturesomeness / Mody M., Gordon S., Lehto X., Adler H. // Tourism Management Perspectives. - 2017. - 24. - Pp. 126-138.

15. Dunlap A. Effectively preparing students for international field placements through a pre-departure class / Dunlap A., Mapp S. C. // Social Work Education. -2017. - 36(8). - Pp. 893-904. 